\title{
Characterization of Phytophthora Species from Leaves of Nursery Woody Ornamentals in Tennessee
}

\author{
Ryan S. Donahoo ${ }^{1}$ \\ USDA-ARS U.S. Vegetable Laboratory, 2700 Savannah Highway, \\ Charleston SC 29414
}

\section{Kurt H. Lamour}

Department of Entomology and Plant Pathology, University of Tennessee, Knoxville TN 37996

\section{Additional index words. Phytophthora, Ericaceae, AFLP}

\begin{abstract}
Species of Phytophthora are ubiquitous in ornamental production resulting in significant crop losses. In Tennessee, national surveys for the sudden oak death pathogen Phytophthora ramorum in 2004 and 2005 led to the isolation of Phytophthora species causing disease in nursery-grown or handled woody ornamentals or both. Isolates recovered were identified to species using direct sequencing of the internal transcribed spacer and examination of morphological characters. Six known species (P. cactorum, $P$. citricola, $P$. citrophthora, $P$. nicotianae, $P$. palmivora, $P$. tropicalis) and one newly described species $(P$. foliorum) were recovered from ericaceous hosts. The most common species recovered were $\boldsymbol{P}$. citricola and $\boldsymbol{P}$. citrophthora. Genetic analysis using amplified fragment length polymorphism (AFLP) markers revealed intraspecific genotypic diversity as well as isolates with identical AFLP genotypes from multiple locations across multiple years. This work provides evidence for species and genotypic diversity of Phytophthora recovered in Tennessee as well as insight into the movement of individual genotypes in woody ornamental production.
\end{abstract}

United States retail nursery sales are valued at $\$ 147.8$ billion annually and southeastern states account for $10 \%$ of this value (Hall et al., 2007). Ericaceous hosts such as azalea, pieris, and rhododendron offer nurserymen attractive high-value crops. Whether produced in ground beds or containers, these hosts are susceptible to at least nine species of Phytophthora (Erwin and Ribeiro, 1996; Werres et al., 2001). Phytophthora cinnamomi, $P$. cactorum, $P$. cryptogea, $P$. lateralis, $P$. megasperma, and P. gonapodyoides have been reported to cause root rot (Erwin and Ribeiro, 1996; Hoitink and Schmitthenner, 1974; Werres et al., 2001). Species causing twig blight symptoms include $P$. cactorum, $P$. cambivora, $P$. citricola, $P$. citrophthora, $P$. nicotianae, and $P$. ramorum (Blomquist et al., 2005; Hwang et al., 2006; Schwingle et al., 2007; Werres et al., 2001). Those causing leaf spot or isolated from leaves include $P$. citricola, $P$. citrophthora, $P$. foliorum, $P$. ramorum, $P$. syringae, and $P$. tropicalis (Gerlach et al., 1974; Hong et al., 2006; Werres et al., 2001). Since the identification and federal regulation of the sudden oak death pathogen $P$. ramorum, there have been a number of monitoring efforts put in place, including nationwide surveys of nurseries and surrounding forested areas (Rizzo

Received for publication 26 Feb. 2008. Accepted for publication 14 May 2008.

${ }^{1}$ To whom reprint requests should be addressed; e-mail Ryan.Donahoo@ars.usda.gov et al., 2002; Stokstad, 2004; Werres et al., 2001).

Nursery production facilities with densely grown plants, intensive cropping at the same site, movement of nursery stock, and use of recycled irrigation water provide multiple opportunities for infection by Phytophthora species (Ribeiro and Linderman, 1991). Irrigation water used in horticultural production facilities is routinely collected to reduce environmental effects and overall production costs (Bush et al., 2003; Lamour et al., 2003). Phytophthora species produce lemon-shaped sporangia in the presence of high moisture or free water that can be dispersed directly or can release motile zoospores (Bush et al., 2003; Lamour et al., 2003; Themann et al., 2002). Free water significantly contributes to the dispersal of Phytophthora species and irrigation sources can serve as reservoirs for species like $P$. cactorum, $P$. cinnamomi, P. citricola, P. citrophthora, P. cryptogea, P. megasperma, $P$. nicotianae, $P$. syringae, and P. tropicalis (Hong et al., 2006; MacDonald et al., 1994; Yamak et al., 2002). Recovery of $P$. citrophthora and P. citricola has been demonstrated to fluctuate seasonally in production facilities (MacDonald et al., 1994).

To date, there have been few reports or characterization of Phytophthora species recovered from nursery hosts in the state of Tennessee. During 2004 and 2005, the following species of Phytophthora were recovered from ericaceous hosts while testing leaves from Tennessee nurseries for the sudden oak death pathogen: P. cactorum,
P. citricola, P. citrophthora, $P$. nicotianae, $P$. tropicalis, and $P$. foliorum sp. nov. (Donahoo et al., 2006). Phytophthora species produce specialized structures allowing for their survival and spread, including a thick-walled sexual spore (oospore), a thick-walled asexual spore (chlamydospore), and an asexual sporangium capable of undergoing cleavage resulting in multiple motile zoospores. The production of oospores can require the interaction of two mating types for some species (heterothallism) (e.g., $P$. nicotianae and $P$. tropicalis), may be accomplished with a single isolate (homothallism) (e.g., P. cactorum, $P$. citricola, and $P$. foliorum), or may be entirely absent (e.g., P. citrophthora).

Identification of Phytophthora to the species level was traditionally based on morphological characters. More recently, a variety of nuclear and mitochondrial gene sequences have been used to support, refine, and, in some cases, expand the species definitions in the genus. The internal transcribed spacer (ITS) has proven an invaluable tool in Phytophthora species identification (Cooke et al., 2000; Schwingle et al., 2007). ITS sequence data, although useful for distinguishing species, is too conserved to resolve diversity within a species (Kroon et al., 2004; Schwingle et al., 2007). A variety of genetic tools have been used to characterize the diversity of Phytophthora isolates within species, including isozymes, restriction fragment length polymorphisms, random amplified polymorphic DNA markers, microsatellites, and amplified fragment length polymorphism (AFLP) markers (Bhat and Browne, 2007; Forster et al., 1990; Gevens et al., 2008; Ivors et al., 2004; Oudemans et al., 1994; Silvar et al., 2006; Vos et al., 1995). We describe the diversity of Phytophthora isolates recovered from ericaceous hosts at nurseries throughout the state of Tennessee using a combination of DNA and morphological-based approaches. Our goal was to document the presence of Phytophthora species in Tennessee nurseries and to examine the potential mechanisms for dispersal.

\section{Materials and Methods}

Fungal cultures. Isolates used in this study are listed in Table 1. All cultures were obtained from leaf samples of azalea, pieris, or rhododendron during the summers of 2004 and 2005. Leaves were collected as part of the Tennessee survey for the sudden oak death pathogen Phytophthora ramorum. Leaf tissue from the edge of foliar lesions was plated on corn meal agar (Sigma, St. Louis) amended with PARP (25 ppm pimaricin, 100 ppm ampicillin, 25 ppm rifampicin, and 25 ppm pentachloronitrobenzene) or V8 juice (Campbell Soup Co., Camden, NJ) agar (V8A) $(840 \mathrm{~mL}$ of distilled water, $163 \mathrm{~mL}$ of $\mathrm{V} 8$ juice, $3 \mathrm{~g}$ of $\mathrm{CaCO}_{3}$, and $16 \mathrm{~g}$ of Bacto agar) amended with PARP (Erwin and Ribeiro, 1996). Cultures were subsequently hyphal-tipped to ensure single isolates. Hyphal tipping was accomplished by growing each culture on water agar and then 
Table 1. List of Phytophthora species and their host of origin, location, and observed AFLP cluster group.

\begin{tabular}{|c|c|c|c|c|}
\hline Species/Isolate & Host & Location & $\mathrm{Yr}$ & $\begin{array}{l}\text { AFLP fingerprint } \\
\text { type }\end{array}$ \\
\hline \multicolumn{5}{|l|}{$\overline{P . \text { citricola }}$} \\
\hline LT194 & Pieris & N1 & 2004 & B genotype-ctc 4 \\
\hline LT197 & Pieris & N1 & 2004 & B \\
\hline LT200 & Rhododendron & N1 & 2004 & A genotype-ctc2 \\
\hline LT201 & Pieris & N1 & 2004 & A genotype-ctc2 \\
\hline LT202 & Rhododendron & N1 & 2004 & B genotype-ctc 4 \\
\hline LT204 & Rhododendron & M1 & 2004 & A \\
\hline LT205 & Rhododendron & M1 & 2004 & B \\
\hline LT207 & Rhododendron & M2 & 2004 & A \\
\hline LT216 & Rhododendron & F1 & 2004 & A \\
\hline LT217 & Rhododendron & M3 & 2004 & A \\
\hline LT220 & Rhododendron & M3 & 2004 & A genotype-ctc1 \\
\hline LT223 & Rhododendron & M4 & 2004 & A genotype-ctc1 \\
\hline LT225 & Rhododendron & $\mathrm{N} 2$ & 2004 & A genotype-ctc3 \\
\hline LT230 & Rhododendron & N2 & 2004 & A \\
\hline LT231 & Rhododendron & M3 & 2004 & A \\
\hline LT235 & Azalea & D1 & 2004 & A \\
\hline LT236 & Rhododendron & $\mathrm{C} 1$ & 2004 & A genotype-ctc3 \\
\hline LT729 & Rhododendron & K3 & 2004 & A genotype-ctc1 \\
\hline LT1334 & Rhododendron & B1 & 2005 & A \\
\hline LT1335 & Rhododendron & M1 & 2005 & A \\
\hline \multicolumn{5}{|l|}{ P. citrophthora } \\
\hline LT193 & Pieris & $\mathrm{C} 2$ & 2004 & B genotype-ctp2 \\
\hline LT195 & Pieris & $\mathrm{C} 2$ & 2004 & A genotype-ctp1 \\
\hline LT203 & Pieris & $\mathrm{C} 3$ & 2004 & A \\
\hline LT209 & Rhododendron & $\mathrm{C} 4$ & 2004 & B genotype-ctp4 \\
\hline LT211 & Rhododendron & U1 & 2004 & A genotype-ctp1 \\
\hline LT212 & Rhododendron & P1 & 2004 & B \\
\hline LT213 & Rhododendron & B1 & 2004 & A \\
\hline LT218 & Rhododendron & D1 & 2004 & B genotype-ctp4 \\
\hline LT219 & Pieris & M3 & 2004 & A \\
\hline LT221 & Rhododendron & F1 & 2004 & A \\
\hline LT222 & Rhododendron & $\mathrm{N} 2$ & 2004 & A \\
\hline LT227 & Pieris & M3 & 2004 & A \\
\hline LT228 & Rhododendron & S1 & 2004 & A \\
\hline LT233 & Rhododendron & $\mathrm{C} 5$ & 2004 & A \\
\hline LT726 & Pieris & K3 & 2005 & A \\
\hline LT727 & Pieris & K3 & 2005 & A \\
\hline LT732 & Pieris & M5 & 2005 & B genotype-ctp3 \\
\hline LT733 & Pieris & M5 & 2005 & B genotype-ctp3 \\
\hline LT734 & Pieris & M5 & 2005 & B genotype-ctp2 \\
\hline LT735 & Pieris & M5 & 2005 & B \\
\hline LT737 & Pieris & M5 & 2005 & B \\
\hline LT740 & Pieris & M5 & 2005 & A \\
\hline LT1273 & Pieris & C6 & 2005 & B \\
\hline LT1337 & Rhododendron & M1 & 2005 & B \\
\hline LT 1383 & Rhododendron & N1 & 2005 & A \\
\hline LT1384 & Pieris & $\mathrm{C} 2$ & 2005 & A \\
\hline \multicolumn{5}{|l|}{ P. nicotianae } \\
\hline LT210 & Rhododendron & H1 & 2004 & Genotype-nic1 \\
\hline LT221 & Rhododendron & F1 & 2004 & \\
\hline LT723 & Pieris & $\mathrm{O} 1$ & 2005 & Genotype-nic2 \\
\hline LT724 & Azalea & $\mathrm{L} 1$ & 2005 & Genotype-nic2 \\
\hline LT738 & Azalea & G1 & 2005 & \\
\hline LT742 & Azalea & K3 & 2005 & Genotype-nic2 \\
\hline LT745 & Azalea & S1 & 2005 & Genotype-nic1 \\
\hline \multicolumn{5}{|l|}{ P. tropicalis } \\
\hline LT208 & Rhododendron & $\mathrm{A} 1$ & 2004 & Genotype-trp1 \\
\hline LT232 & Rhododendron & M4 & 2004 & Genotype-trp1 \\
\hline LT234 & Rhododendron & $\mathrm{S} 1$ & 2004 & \\
\hline LT722 & Pieris & $\mathrm{O} 1$ & 2005 & Genotype-trp1 \\
\hline LT728 & Rhododendron & $\mathrm{K} 3$ & 2005 & Genotype-trp2 \\
\hline LT739 & Pieris & G1 & 2005 & \\
\hline LT743 & Pieris & $\mathrm{K} 2$ & 2005 & \\
\hline LT744 & Pieris & $\mathrm{K} 3$ & 2005 & Genotype-trp2 \\
\hline \multicolumn{5}{|l|}{ P. cactorum } \\
\hline LT196 & Rhododendron & E1 & 2004 & Genotype-cac \\
\hline LT198 & Rhododendron & E1 & 2004 & Genotype-cac \\
\hline LT1262 & Azalea & M6 & 2005 & Genotype-cac1 \\
\hline \multicolumn{5}{|l|}{ P. foliorum } \\
\hline 192 & Azalea & M6 & 2004 & Genotype-fol1 \\
\hline 1261 & Azalea & M6 & 2005 & Genotype-fol1 \\
\hline \multicolumn{5}{|l|}{ P. palmivora } \\
\hline 736 & Rhododendron & M7 & 2005 & \\
\hline
\end{tabular}

subculturing a single hyphae from the expanding margin of the culture. Cultures were incubated in the dark at room temperature for 7 to $10 \mathrm{~d}$ and then examined microscopically. Cultures were maintained on V8A PARP and were stored long-term at room temperature $\left(25^{\circ} \mathrm{C}\right)$ as colonized agar discs of V8A in sterile water containing two autoclaved hemp seeds (Caten and Jinks, 1968; Erwin and Ribeiro, 1996). Sporangial production was induced by culturing isolates on V8A plates under ambient lighting. Heterothallic species were paired with Phytophthora capsici tester isolates CBS 121656 (A1) or CBS 121657(A2) and incubated in the dark for 7 to $14 \mathrm{~d}$. Oospore production and mating type was determined by preparing a "squash mount" and observing under a light microscope.

Mefenoxam sensitivity was assessed by placing a 7-mm agar plug from a 1-week-old, hyphal-tipped derived culture on one $100 \times$ $15-\mathrm{mm}$ plate of V8 agar and two $100 \times 15$ $\mathrm{mm}$ plates of V8A amended with $100 \mathrm{ppm}$ mefenoxam (Ridomil Gold EC, Syngenta, Greensboro, NC). Plates were incubated at 23 to $25{ }^{\circ} \mathrm{C}$ for $3 \mathrm{~d}$, and colony diameters were measured. Isolate growth on mefenoxamamended media compared with control media was classified as sensitive ( $\mathrm{S}$, less than $50 \%$ of the control) or insensitive (I, greater than $50 \%$ of the control) (Gevens et al., 2007; Lamour and Hausbeck, 2000).

DNA extraction and genotyping. Mycelium was grown in V8-PARP broth, lyophilized, and genomic DNA was extracted using Qiagen's DNeasy Plant Mini-kit (Valencia, CA). Genomic DNA from all 67 isolates was subjected to AFLP. AFLP was performed using EcoRI and MseI restriction enzymes, adapters, and primers as described previously (Vos et al., 1995). Selective amplifications were done using Eco-AC + Mse-CCC and Eco-AC + Mse-CA primer pairs. Reactions were diluted and labeled in a separate reaction as described previously (Habera et al., 2004). Fluorescently labeled products were resolved on a Beckman-Coulter CEQ8000 capillary genetic analysis instrument (Fullerton, CA). Fragments were confirmed visually and transformed into a binary matrix $(1=$ present, $0=$ absent). The resulting matrix was analyzed with the unweighted pair group method with arithmetic mean as implemented in NTSYSpc2.11a (Rohlf, 2007).

Polymerase chain reaction and internal transcribed spacer sequencing. Polymerase chain reaction (PCR) amplification for the ITS has been described previously and methods are available online (www.phytid.org) (Cooke et al., 2000). PCR-generated amplicons were visually confirmed on $1 \%$ agarose gels. Confirmed amplicons were columnpurified using a QIAquick PCR purification kit (Qiagen, Valencia, CA). Purified PCR products were submitted for direct sequencing in both directions at The University of Tennessee's Molecular Biology Resource Facility. Sequence trace data were assigned base calls using phred, trimmed, and assembled using CodonCode Aligner (CodonCodes, 
Dedham, MA). The consensus sequence from assembled contigs for each individual isolate was used to search the National Center for Biotechnology Information Genbank database.

\section{Results}

In total, 67 Phytophthora isolates were recovered and characterized in this study. AFLP analysis, ITS sequencing, and subsequent database queries, in combination with morphological characterizations, allowed for identification of the following species: $P$. cactorum $(\mathrm{n}=3), P$. citricola $(\mathrm{n}=$ $20), P$. citrophthora $(\mathrm{n}=26), P$. foliorum $(\mathrm{n}=$ $2), P$. nicotianae $(\mathrm{n}=7), P$. palmivora $(\mathrm{n}=1)$, and $P$. tropicalis $(\mathrm{n}=8)$. Resistance to mefenoxam was observed, but only in $P$. citricola $(\mathrm{n}=2)$ and $P$. citrophthora $(\mathrm{n}=4)$. The presence of distinctive oospore morphologies, sporangial dimensions and pedicel characteristics, and mating type reactions were consistent with the identifications made based on ITS sequencing. The exception was the identification and characterization of a new species, P. foliorum (Donahoo et al., 2006).

Species specific clusters were observed with the AFLP data (Fig. 1). The most abundant species recovered was $P$. citrophthora, which appears to be comprised of two subclusters designated A and B. Phytophthora citrophthora isolates with identical AFLP genotypes were recovered from operations up to 285 miles apart. Additionally, $P$. citrophthora isolates with identical AFLP genotypes were recovered from both 2004 and 2005 (Fig. 2; Table 1). The second most commonly recovered species was $P$. citricola, and like $P$. citrophthora, two AFLP groups were observed with identical AFLP genotypes recovered from locations up to 150 miles apart and from 2004 and 2005 (Fig. 3; Table 1). Seven isolates of $P$. nicotianae were recovered, three with the multilocus AFLP genotype nic2, two with the multilcous AFLP genotype nic1, and two with unique AFLP genotypes (Table 1). Eight isolates of $P$. tropicalis were recovered, three isolates shared the multilocus AFLP genotype trp1, two exhibited the multilocus AFLP genotype trp2, and two isolates had unique AFLP genotypes. Phytophthora cactorum and $P$. foliorum were recovered less frequently. In the case of $P$. cactorum, three isolates were recovered in total, two from one location in 1 year and the third recovered from a different location the next year. Isolates of $P$. foliorum with identical AFLP genotypes were recovered from one location in 2004 and 2005.

\section{Discussion}

Seven Phytophthora species were recovered from leaves of nursery-grown ericaceous hosts as part of the sudden oak death survey in Tennessee. The most commonly recovered species were $P$. citricola $(29 \%)$ and $P$. citrophthora (38\%) accounting for $66 \%$ of total isolates recovered. This may be the result of sampling bias or may reflect the prevalence of these two species in Tennessee
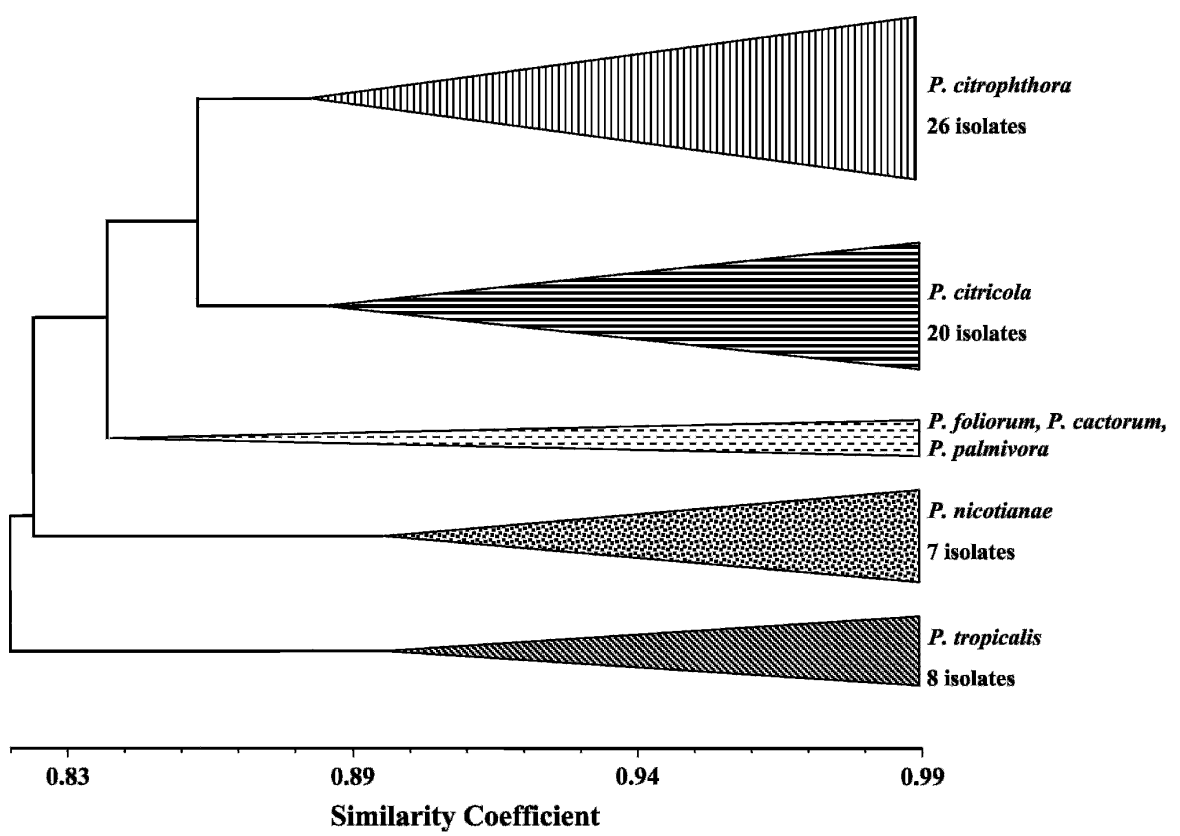

Fig. 1. Genetic similarity of Phytophthora isolates recovered from ericaceous hosts. Isolates were analyzed using the selective $\mathrm{E}-\mathrm{AC} / \mathrm{MCCC}$ primer pairs to produce an amplified fragment length polymorphism profile and similarity assessed using the unweighted pair group with mathematical averaging (UPGMA). Isolates/species clustering together have been grouped for illustrative purposes.

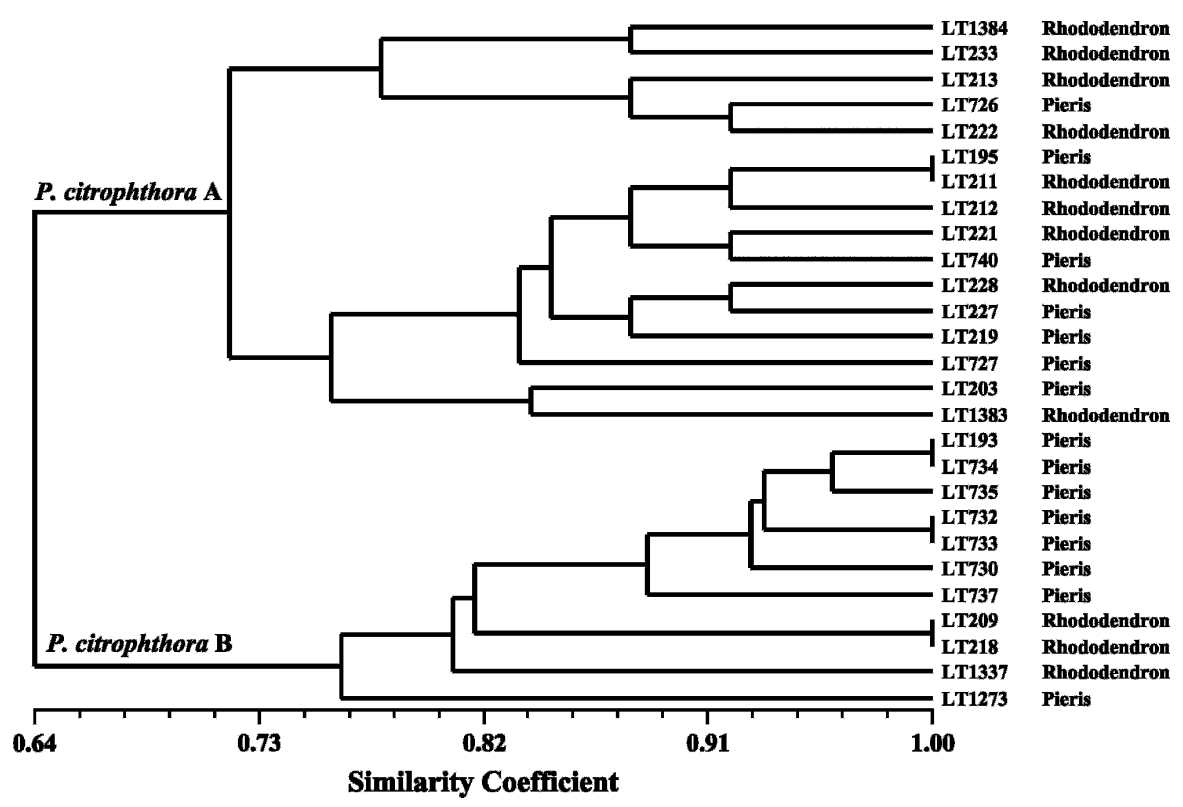

Fig. 2. Genotypic similarity of Phytophthora citrophthora isolated form ericaceous hosts in Tennessee based on 37 amplified fragment length polymorphism fragments produced using the E-AC/MCC selective primer combination.

nursery production facilities. Previous reports indicate that $P$. citricola and $P$. citrophthora are commonly associated with containergrown nursery plants or irrigation sources associated with nursery production (Bush et al., 2003; Ferguson and Jeffers, 1999; MacDonald et al., 1994; Schwingle et al., 2007; Themann et al., 2002; Yamak et al., 2002). Similarly, the remaining species identified in this study, although limited in their numbers, have also been recovered from similar hosts/sources (Bush et al., 2003; Ferguson and Jeffers, 1999; Hong et al.,
2006; Schwingle et al., 2007). The finding of these species is not surprising because container-grown nursery crops are often handled by multiple facilities both inside and outside of Tennessee during production and the movement of Phytophthora between facilities is likely common.

The extent of genetic diversity within species varied with the actual number of isolates recovered. As a result of the limited number of samples, it is difficult to accurately assess the genetic diversity of $P$. cactorum, $P$. foliorum, $P$. nicotianae, and $P$. tropicalis in 


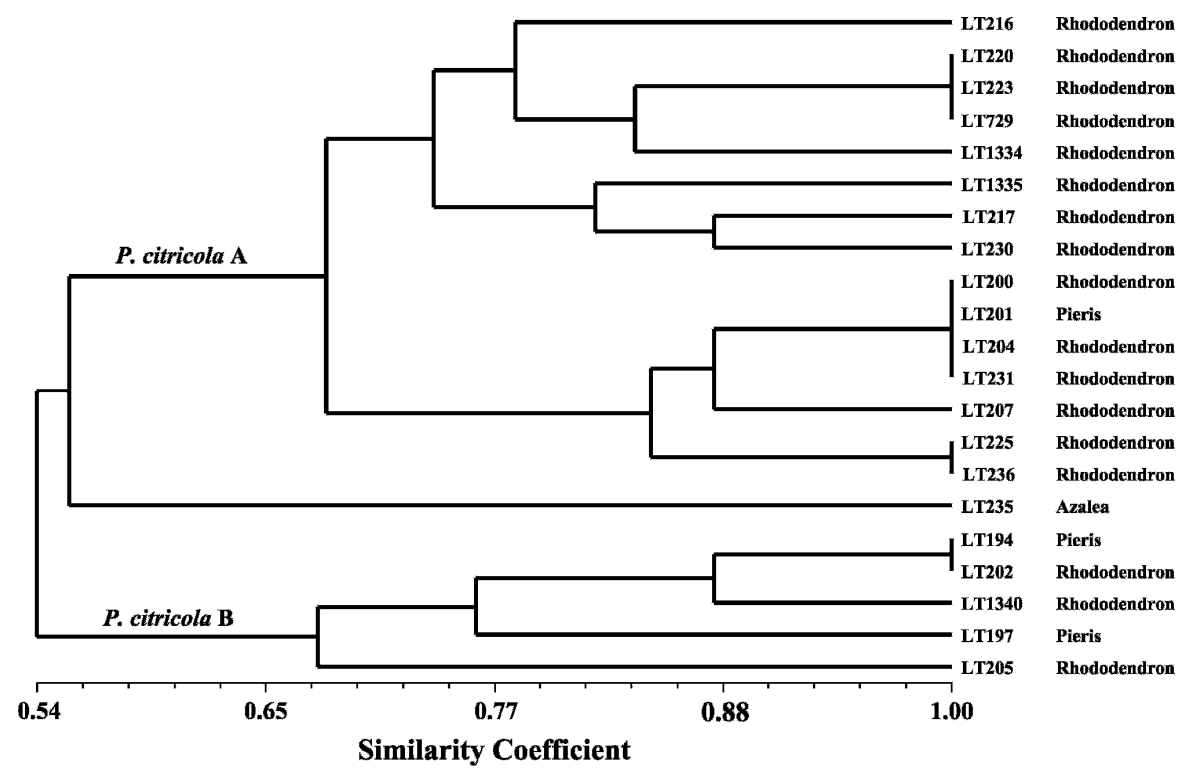

Fig. 3. Genotypic similarity of Phytophthora citricola isolated form ericaceous hosts in Tennessee based on 25 amplified fragment length polymorphism fragments produced using the E-AC/MCC selective primer combination.

Tennessee. It has been shown that $P$. cactorum is dispersed throughout southeastern states on strawberry transplants, and because it is homothallic, it is expected to exhibit a low level of genetic diversity (Huang et al., 2004). Populations of $P$. cactorum recovered from strawberries in the United States appear to exhibit greater genetic diversity and are distinct from those recovered in Europe (Eikemo et al., 2004; Hantula et al., 2000; Huang et al., 2004). Additionally, isolates of $P$. cactorum recovered from rhododendron in Germany was found to be similar to both European Union and U.S. strawberry isolates, nonpathogenic on strawberry, and exhibited larger oospores (Hantula et al., 2000). Future studies addressing the diversity among $P$. cactorum isolates from rhododendron in the European Union and U.S. populations may further clarify dissemination of this species.

Isolates of $P$. foliorum from California were found to be identical to the isolates recovered from Tennessee (Donahoo et al., 2006). The seven $P$. nicotianae isolates exhibited one of three AFLP genotypes and a high degree of genetic similarity has been reported for this species (Lamour et al., 2003; Zhang et al., 2003). Little is known about $P$. tropicalis in the continental United States. From our findings here and reports from Virginia and South Carolina, it may be concluded that this species has recently been introduced (Hong et al., 2006; Leahy, 2006). Additionally, $P$. tropicalis isolates recovered in Tennessee can be distinguished from those recovered from cacao or macadamia in the original $P$. tropicalis species description based on nuclear and mitochondrial nucleotide sequences (Donahoo and Lamour, unpublished data).

The larger sample sets revealed considerable diversity within $P$. citrophthora and
P. citricola. Diversity within $P$. citricola has been documented previously and up to five subgroups have been observed (Forster et al., 1990; Oudemans et al., 1994). A study characterizing $P$. citricola from diverse hosts in California over 30 years suggests that genotypes could be correlated with host and geographical origin (Bhat and Browne, 2007). The authors suggest that the observed genetic diversity may arise by outcrossing similar to what has been observed in the homothallic P. sojae (Bhat and Browne, 2007; Bhat and Schmitthenner, 1993; MacGregor et al., 2002). Phytophthora citrophthora is not known to complete the sexual stage and is considered sterile (Erwin and Ribeiro, 1996). The mechanisms leading to the observed diversity within isolates of $P$. citrophthora are not known at this time.

Although genotypic diversity was present within all the species studied except $P$. foliorum, we were also able to document the spatiotemporal persistence of isolates carrying identical multilocus AFLP genotypes over 2 years. This may be accomplished through the production of homothallic sexual spores in the case of $P$. foliorum, $P$. cactorum, and $P$. citricola. In addition, chlamydospores may play an important role in allowing for the persistence of species like $P$. citrophthora, $P$. nicotianae, and $P$. tropicalis. Furthermore, it is possible that these species of Phytophthora are persisting as mycelium in infected host tissues.

An important finding is that all of these isolates were recovered from leaves exhibiting primarily nonspecific brown lesions. In most cases, the leaves were collected from plants that were to be sold within the next weeks or months. This provides a unique opportunity for dispersal both within the nursery production facility and to the environment at large. The sale of contaminated nursery stock allows Phytophthora to be dispersed into many different settings and the description of isolates described here may provide a useful baseline for understanding epidemics occurring both within nursery facilities and also in the natural environment (Coffey, 1991).

\section{Literature Cited}

Bhat, R.G. and G.T. Browne. 2007. Genetic diversity in populations of Phytophthora citricola associated with horticultural crops in California. Plant Dis. 91:1556-1563.

Bhat, R.G. and A.F. Schmitthenner. 1993. Genetic crosses between physiologic races of Phytophthora sojae. Exp. Mycol. 17:122-129.

Blomquist, C.L., T. Irving, N. Osterbauer, and P.W. Reeser. 2005. Phytophthora hibernalis: A new pathogen on Rhododendron and evidence of cross amplification with two PCR detection assays for Phytophthora ramorum. Online. Plant Health Prog. DOI: 10.1094/PHP2005-0728-01-HN.

Bush, E.A., C.X. Hong, and E.L. Stromberg. 2003. Fluctuations of Phytophthora and Pythium spp. in components of a recycling irrigation system. Plant Dis. 87:1500-1506.

Caten, C.E. and J.L. Jinks. 1968. Spontaneous variability of single isolates of Phytophthora infestans. I. Cultural variation. Can. J. Bot. 46:329-348

Coffey, M.D. 1991. Strategies for the integrated control of soilborne Phytophthora species, p. 399-410. In: Luca, J.A., R.C. Shattock, D.S. Shaw, and L.R. Cooke (eds.). Phytophthora. Press Syndicate of the University of Cambridge, Cambridge, UK.

Cooke, D.E.L., A. Drenth, J.M. Duncan, G. Wagels, and C.M. Brasier. 2000. A molecular phylogeny of Phytophthora and related oomycetes. Fungal Genet. Biol. 30:17-32.

Donahoo, R., C.L. Blomquist, S.L. Thomas, J.K Moulton, D.E.L. Cooke, and K.H. Lamour. 2006. Phytophthora foliorum sp. nov., a new species causing leaf blight of azalea. Mycol. Res. 110:1309-1322.

Eikemo, H., S.S. Klemsdal, I. Riisberg, P.J.M. Bonants, A. Stensvand, and A.M. Tronsmo. 2004. Genetic variation between Phytophthora cactorum isolates differing in their ability to cause crown rot in strawberry. Mycol. Res. 108:317-324.

Erwin, D.C. and O.K. Ribeiro. 1996. Phytophthora diseases worldwide. American Phytopathological Society, St. Paul, MN

Ferguson, A.J. and S.N. Jeffers. 1999. Detecting multiple species of Phytophthora in container mixes from ornamental crop nurseries. Plant Dis. 83:1129-1136.

Forster, H., P. Oudemans, and M.D. Coffey. 1990. Mitochondrial and nuclear DNA diversity within six species of Phytophthora. Exp. Mycol. 14:18-31.

Gerlach, W.W.P., H.A.J. Hoitink, and C.W. Ellett 1974. Shoot blight and stem dieback of Pieirs japonica caused by Phytophthora citricola P. citrophthora, and Botryosphaeria dothidea. Phytopathology 64:1368-1370.

Gevens, A.J., R.S. Donahoo, K.H. Lamour, and M.K. Hausbeck. 2007. Baiting Phytophthora capsici from Michigan surface irrigation water and characterization of isolates. Phytopathology 97:421-428.

Gevens, A.J., R.S. Donahoo, K.H. Lamour, and M.K. Hausbeck. 2008. Characterization of Phytophthora capsici causing foliar and pod 
blight of snap bean in Michigan. Plant Dis. 92:201-209.

Habera, L., N. Smith, R. Donahoo, and K. Lamour. 2004. Use of a single primer to fluorescently label selective amplified fragment length polymorphism reactions. Biotechniques 37:902-903.

Hall, C.R., A.W. Hodges, and J.J. Haydu. 2007. Economic impacts of the green industry in the United States. Vol. 2008. Univ. of Florida, Gainesville, FL. <http://edis.ifas.ufl.edu/pdffiles/ FE/FE56600.pdf>.

Hantula, J., A. Lilja, H. Nuorteva, P. Parikka, and S. Werres. 2000. Pathogenicity, morphology and genetic variation of Phytophthora cactorum from strawberry, apple, rhododendron, and silver birch. Mycol. Res. 104:1062-1068.

Hoitink, H.A.J. and A.F. Schmitthenner. 1974. Relative prevelance and virulence of Phytophthora species involved in Rhododendron root rot. Phytopathology 64:1371-1374.

Hong, C.X., P.A. Richardson, and P. Kong. 2006. Phytophthora tropicalis isolated from diseased leaves of Pieris japonica and Rhododendron catawbiense and found in irrigation water and soil in Virginia. Plant Dis. 90:525.

Huang, H., S.N. Jeffers, D.R. Layne, and G. Schnabel. 2004. AFLP analysis of Phytophthora cactorum isolates from strawberry and other hosts: Implications for identifying the primary source of inoculum. Plant Dis. 88:714-720.

Hwang, J., C.Y. Warfield, K.C. Parker, and D.M. Benson. 2006. First report of Phytophthora cambivora on hybrid rhododendron in North Carolina. Plant Health Prog. Online. 10.1094/ PHP-2006-0828-01-BR.

Ivors, K.L., K.J. Hayden, P.J.M. Bonants, D.M. Rizzo, and M. Garbelotto. 2004. AFLP and phylogenetic analysis of North American and European populations of Phytophthora ramorum. Mycol. Res. 108:378-392.

Kroon, L.P.N.M., F.T. Bakker, G.B.M. van den Bosch, P.J.M. Bonants, and W.G. Flier. 2004.
Phylogenetic analysis of Phytophthora species based on mitochondrial and nuclear DNA sequences. Fungal Genet. Biol. 41:766782.

Lamour, K.H., M.L. Daughtrey, D.M. Benson, J. Hwang, and M.K. Hausbeck. 2003. Etiology of Phytophthora drechsleri and $P$. nicotianae $(=P$. parasitica) diseases affecting floriculture crops. Plant Dis. 87:854-858.

Lamour, K.H. and M.K. Hausbeck. 2000. Mefenoxam insensitivity and the sexual stage of Phytophthora capsici in Michigan cucurbit fields. Phytopathology 90:396-400.

Leahy, R.M. 2006. Phytophthora blight of pothos. F.D.A.C. Services, Division of Plant Industry, Gainesville, FL.

MacDonald, J.D., M.S. Ali-Shtayeh, J. Kabashima, and J. Stiles. 1994. Occurrence of Phytophthora species in recirculated nursery irrigation effluents. Plant Dis. 78:607-611.

MacGregor, T., M. Bhattacharyya, B.M. Tyler, R.G. Bhat, A.F. Schmitthenner, and M. Gijzen. 2002. Genetic and physical mapping of Avrla in Phytophthora sojae. Genetics 160:949959.

Oudemans, P., H. Forster, and M.D. Coffey. 1994. Evidence for distinct isozyme subgroups within Phytophthora citricola and close relationships with P. capsici and P. citrophthora. Mycol. Res. 98:189-199.

Ribeiro, O.K. and R.G. Linderman. 1991. Chemical and biological control of Phytophthora species in woody plants, p. 399-410. In: Luca, J.A., R.C. Shattock, D.S. Shaw, and L.R. Cooke (eds.). Phytophthora. Press Syndicate of the University of Cambridge, Cambridge, UK.

Rizzo, D.M., M. Garbelotto, J.M. Davidson, G.W. Slaughter, and S.T. Koike. 2002. Phytophthora ramorum as the cause of extensive mortality of Quercus spp. and Lithocarpus densiflora in California. Plant Dis. 86:205-214.
Rohlf, F.J. 2007. NTSYSpc: Numerical taxonomy system. Exeter Publishing, Ltd., Setauket, NY.

Schwingle, B.W., J.A. Smith, and R.A. Blanchette. 2007. Phytophthora species associated with diseased woody ornamentals in Minnesota nurseries. Plant Dis. 91:97-102.

Silvar, C., F. Merino, and J. Diaz. 2006. Diversity of Phytophthora capsici in Northwest Spain: Analysis of virulence, Metalaxyl response, and molecular characterization. Plant Dis. 90:1135-1142.

Stokstad, E. 2004. Nurseries may have shipped sudden oak death pathogen nationwide. Science 303:1959.

Themann, K., S. Werres, R. Luttmann, and H.A Diener. 2002. Observations of Phytophthora spp. in water recirculation systems in commercial hardy ornamental nursery stock. Eur. J. Plant Pathol. 108:337-343.

Vos, P., R. Hogers, M. Bleeker, M. Reijans, T. van de Lee, M. Hornes, A. Frijters, J. Pot, and M. Kuiper. 1995. AFLP: A new technique for DNA fingerprinting. Nucleic Acids Res. 23: 4407-4414.

Werres, S., R. Marwitz, W.A. Man In't Veld, W.A.M. de Cock, P.J.M. Bonants, M. De Weerdt, E. Ilieva, and R.P. Bayyen. 2001. Phytophthora ramorum sp. nov., a new pathogen on Rhododendron and Viburnum. Mycol. Res. 105:1155-1165.

Yamak, F., T.L. Peever, G.G. Grove, and R.J. Boal. 2002. Occurrence and identification of Phytophthora spp. pathogenic to pear fruit in irrigation water in the Wenatchee River valley of Washington state. Phytopathology 92:1210 1217.

Zhang, X.G., W.X. Sun, L. Guo, J.F. Fu, and C.J. Chang. 2003. Genetic and pathogenic variation among Tobacco Black Shank strains of Phytophthora parasitica var. nicotianae from the main tobacco growing in China. J. Phytopathol. 151:259-266. 